\title{
Evaluation of a Tool that Enables Cancer Patients to Participate in the Decision-Making Process during Treatment Selection
}

\author{
Kumi Chubachi ${ }^{1}$, Junko Umihara ${ }^{2}$, Akiko Yoshikawa ${ }^{1}$, Shinji Nakamichi ${ }^{1}$, \\ Susumu Takeuchi ${ }^{1}$, Masaru Matsumoto ${ }^{1}$, Akihiko Miyanaga ${ }^{1}$, Yuji Minegishi ${ }^{1}$, \\ Kazuo Yamamoto ${ }^{1}$, Masahiro Seike ${ }^{1}$, Akihiko Gemma ${ }^{1}$ and Kaoru Kubota ${ }^{1}$ \\ ${ }^{1}$ Department of Pulmonary Medicine and Oncology, Graduate School of Medicine, Nippon Medical School, Tokyo, Japan \\ ${ }^{2}$ Center for Medical Education, Nippon Medical School, Tokyo, Japan
}

Background: Patient participation in decisions related to their treatment is strongly recommended. This study was conducted to develop and evaluate a support tool that can help patients make decisions related to their own treatment.

Methods: Twenty cancer patients who were hospitalized for first-line treatment were enrolled. Before hospitalization, a 'Check sheet on treatment selection', which contained 14 questions, was distributed to patients and/or their families. After hospitalization, the attending physician explained the treatment while referring to the written check sheet. At discharge, patients' responses to the 'Questionnaire on check sheet and treatment selection' were collected to evaluate the utility of the check sheet. Finally, the 'Questionnaire of the check sheet' was handed to the attending physician to evaluate.

Results: Of the fourteen patients who responded to the questionnaire, all indicated that the check sheets were helpful for decision-making and that using the sheets empowered them to ask their doctors questions. Only one person felt uncomfortable with compiling the check sheet. Physicians stated that the check sheet facilitated patient decision-making and improved communication with patients. However, some felt that this activity increased the administrative burden of medical professionals.

Conclusion: Almost all patients stated that the present check sheet was useful as a decision support tool and facilitated communication between doctors and patients. Before incorporation into general clinical practice, this increased benefit should be weighed against the potential extra administrative workload imposed on clinicians. (J Nippon Med Sch 2021; 88: 273-282)

Key words: decision support, treatment selection, cancer, patient-physician communication

\section{Introduction}

Cancer treatment choice is critical for patient survival, quality of life, and satisfaction with medical care ${ }^{1}$. Over the last two decades, patient participation in treatmentrelated decision-making has been recognized as an ethically and clinically desirable activity ${ }^{2-4}$. Approaches to treatment-related decision-making are classified as paternalistic (physician control), informed (patient autonomy), and shared ${ }^{5}$. In Asian countries, including Japan, the doctor-patient relationship has been formed in the context of a paternalistic, hierarchical culture. In Japan, phy- sicians have generally been the main decision makers for choices regarding treatment and care, and patients and their families have accepted their recommendations. This type of a traditional decision-making process, in which the patient leaves the decision to her/his physician, has been described by researchers and referred to in Japanese as the omakase style ${ }^{6-9}$. However, in such a physicianpatient relationship, it can be difficult for patients to obtain information that would allow them to participate in decision-making ${ }^{6}$. There is evidence that the style of patient-physician communication has a significant impact

Correspondence to Kaoru Kubota, Department of Pulmonary Medicine and Oncology, Graduate School of Medicine, Nippon

Medical School, 1-1-5 Sendagi, Bunkyo-ku, Tokyo 113-8603, Japan

E-mail: kkubota@nms.ac.jp

https://doi.org/10.1272/jnms.JNMS.2021_88-401

Journal Website (https://www.nms.ac.jp/sh/jnms/) 
on decision-making processes related to treatment choice and that patient participation in decision-making increases patient satisfaction with the ultimate treatment selection $^{10-13}$. Moreover, greater satisfaction with the selected treatment is associated with better health outcomes $^{14,15}$.

Despite these benefits, there is no consensus on the best approach for including patients in the decisionmaking process ${ }^{16-21}$. This is especially true in clinical oncology practice, where patients' preferences related to the decision-making process differ according to disease stage (i.e., those at diagnosis versus those with terminal disease). Furthermore, the preference for ceding control to physicians is greater when the situation involves potential mortality or when the respondent's health status is deteriorating ${ }^{22}$. Thus, there is increasing recognition that, to provide individualized care, healthcare professionals should assess individual patient preferences. The corollary of this is that putting pressure on patients to decide a treatment opinion could have negative psychosocial consequences, particularly if the patient does not wish to be the final decision maker $^{20}$. To fully participate in decision-making, patients must of course receive information about the disease. While some patients may proactively seek out this information, others may be less confident in asking for advice, even though they want to know more ${ }^{7}$. Recent Japanese studies indicated that some patients want to be more informed, yet cannot formalize the questions they would like to ask and therefore are keen to know the types of questions other patients have in mind ${ }^{23,24}$. In light of these issues, we developed a decision support tool to make it easier for cancer patients to ask questions or obtain information on treatment selection, and to improve communication with doctors. Herein, we describe our findings related to the utility of this decision support tool and discuss its potential limitations.

\section{Material and Methods}

The study protocol was approved by the ethics committee of Nippon Medical School Hospital. Twenty cancer patients who were hospitalized for first-line medical treatment at the Department of Pulmonary Medicine and Oncology at Nippon Medical School Hospital between November 2013 and April 2014 were enrolled (Table 1). Eligibility criteria included a cytological or histological diagnosis of cancer, with intention to provide first-line medical cancer treatment including chemotherapy or radiotherapy in hospital. After obtaining written informed consent as an outpatient at the timing when hospitalization was decided, the 'Check sheet on treatment selection' was distributed to patients and/or their families, who were asked to provide answers. This check sheet includes a structured list of questions covering the items a patient may want to ask their physician regarding their illness, treatment, and living environment (Table 2, 3). The sheet consists of 14 questions, including two related to medical conditions, two regarding treatment, nine on their living environment, and a final open-ended question, ie, 'In addition to these questions, please mention anything else you want to ask the doctor. 'Patients' comments could be added inside parentheses after each question. After the patient was hospitalized, the attending physician in hospital explained the treatment and received questions while referring to the check sheet. When patients were discharged from the hospital, their responses to the 'Questionnaire on check sheet and treatment selection' (Table 4,5) were collected to evaluate the utility of the initial check sheet. The doctors were also asked their opinions on the check sheet (Table 6, 7).

\section{Results}

\section{Patient Characteristics}

Twenty patients considered eligible for enrollment agreed to participate in the study. Patient demographics are presented in Table 1 . The median age of participants was 65.5 years (range 34-72 years). The primary cancer cites were the lung and thymus. Most participants had Stage IIIB or worse disease at diagnosis. The breakdown of treatments given upon the first hospital admission was postoperative adjuvant chemotherapy for 5 , chemoradiotherapy for 5 , radiation therapy for 1 , and chemotherapy for 9 .

\section{Check Sheet on Treatment Selection}

The check sheet was collected from all patients. The results of the check sheet on treatment selection are shown in Figure 1. Regarding questions related to medical conditions and diagnosis (Q1, Q2), most respondents understood their diagnosis as it was explained to them as outpatients, but a quarter of respondents wanted additional explanation of the various stages of their disease. Responses to questions about treatment (Q3-9, Q12, Q13) indicated that most respondents understood the treatment method presented. However, many had no sense of the relative efficacy of the recommended therapy or were anxious about the effects of the treatment. In the two questions on living environment during treatment (Q10, Q11), about half of the patients reported economic anxi- 
Table 1 Clinical characteristics of study participants

\begin{tabular}{lc}
\hline Participants & 20 \\
Gender: Male, Female, (\%) & $17(85), 3(15)$ \\
Age: median (range) & $65.5(34-73)$ \\
Cancer type (lung cancer/thymic cancer) & $(19 / 1)$ \\
Stage (IIA/IIB/IIIB/IV/Not Reported) & $(2 / 1 / 8 / 7 / 1)$ \\
Scheduled treatments (Postoperative adjuvant chemotherapy/ & $(5 / 5 / 1 / 9)$ \\
Chemoradiotherapy/Radiation therapy/Chemotherapy) & $(15 / 5)$ \\
Performance status (0/1) & $16(80), 4(20)$ \\
Family living together Yes (\%), No (\%) &
\end{tabular}

Table 2 Check sheet on treatment selection

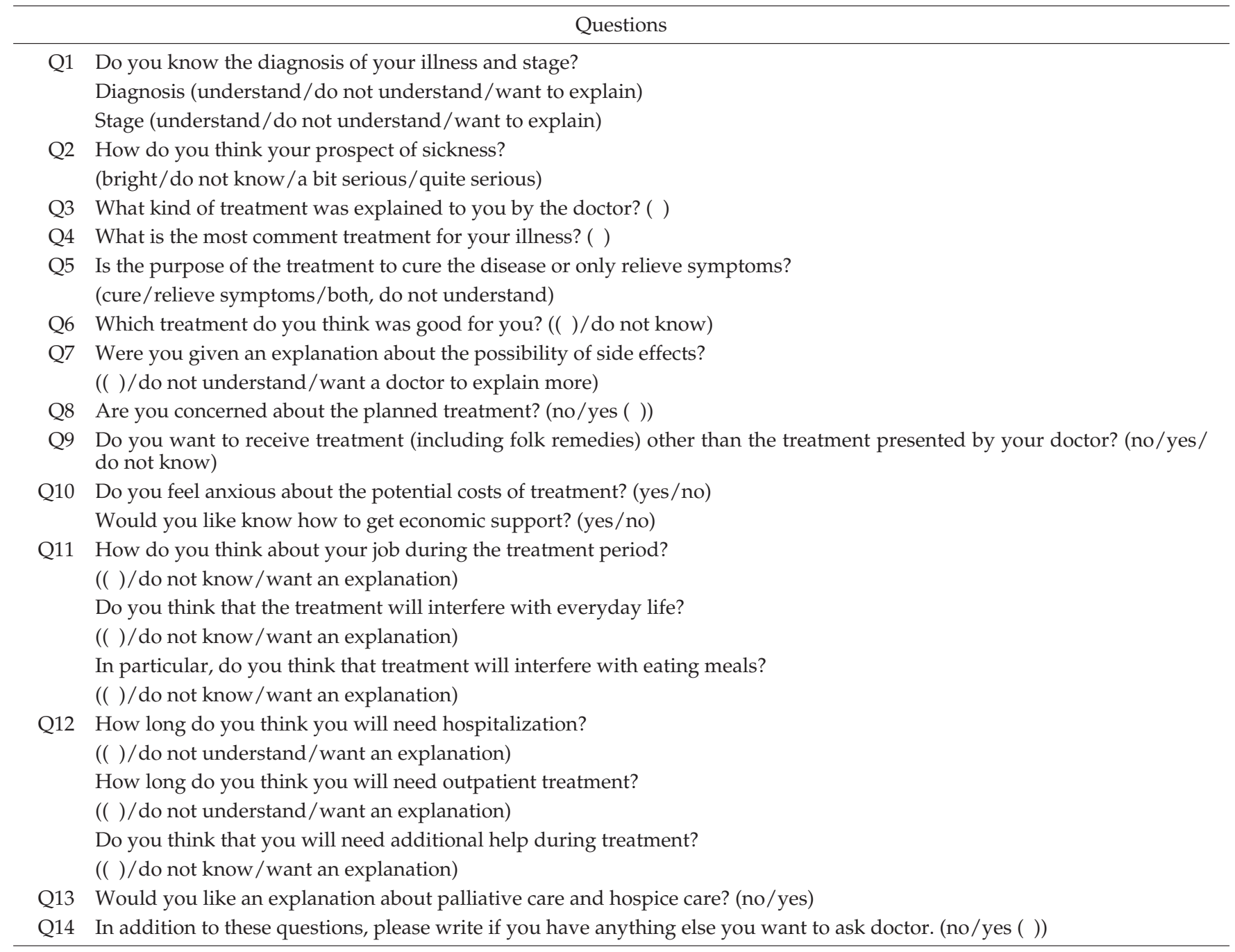

ety; this frequency is almost identical to that reported in a study of patients with advanced cancer ${ }^{25}$. Some patients also wanted to express more direct physical concerns, such as trouble with eating meals.

Questionnaire on Check Sheet and Treatment Selection

This questionnaire was returned from 14 of the 20 pa- tients to whom it was distributed. The results for the check sheet on treatment selection are shown in Figure 2. All respondents answered that the check sheet was useful for organizing ideas on decision-making. In addition, all respondents who answered the question related to the ease of posing questions to the doctor indicated that the check sheet improved their communication with the phy- 
Table 3 治療選択に関するチェックシート

1 ご自分の病気の診断名，ステージ（病気の進行状態）をご存知ですか？

診断名（），わからない, 説明してほしい

ステージ（）,わからない，説明してほしい

2 ご自分の病気の見通し（今後について）をどうとらえていますか?

見通しは明るい, 何とも言えない, 少し深刻, かなり深刻

3 医師から説明された治療法にはどんなものがありましたか.

4 ご自分の病気に関して, どの治療法が一般的に行れていると説明されましたか?

.

5 治療の目的は, 病気を治すことですか? 症状の改善のみですか?

病気を治す, 症状改善のみ, 両方, 分からない

6 ご自分では，どの治療法がいいと思いましたか？（），わからない

7 ご自分の選ぼうとしている治療法に関する副作用についてどんな可能性があると説明をうけましたか? （），わからない，もっと説明してほしい

8 ご自分の選ぼうとしている治療法に関する不安はありますか，ある場合は不安について教えてください， ない, ある（）

9 医師から説明された治療法以外の治療法（民間療法などを含む）を受けたいとお思いですか？ 受ける気はない，受けたい，わからない

10 治療に際して, 経済的な不安を感じていますか? はい, いいえ

経済的サポートを受ける方法について説明を受けたいですか？はい，いいえ

11 治療期間中のご自身の仕事について，どのようになると予想されていますか？

( ), わからない, 説明して欲しい

治療期間中の日常生活に何か支障がでるとお考えですか？

（），わからない, 説明して欲しい

特に，治療期間中の食事について支障があるとお考えですか？

( )，わからない, 説明して欲しい

12 入院期間はどのくらいになると理解されていますか?

( ), わからない, 説明して欲しい

外来治療の期間はどのくらいになると理解していますか?

（），わからない, 説明して欲しい

入院中や通院中の手助けがどのくらい必要であると理解していますか?

( ), わからない, 説明して欲しい

13 緩和ケア, ホスピスケアについて説明を希望されますか？いいえ，はい

14 これ以外に，医師にお聞きになりたいことがあれば記載なさってくださいいいい，はい，（）

Table 4 Questionnaire on check sheet and treatment selection $(n=14)$

\begin{tabular}{cl}
\hline Q1 & \multicolumn{1}{c}{ Questions } \\
Did the check sheet help you to organize ideas when selecting treatment? \\
(quite helpful/a little helpful/not very helpful/not helpful at all) \\
Q2 \\
Did you feel that the check sheet made it easier to ask doctors or talk about questions? \\
(very easy to talk/a little easy to talk/hard to talk a bit/hard to talk) \\
Q3 $\begin{array}{l}\text { Did you fully understand the treatment options after listening to the doctor's explanation, and was your talk with the doc- } \\
\text { tor satisfactory? }\end{array}$ \\
Please express your satisfaction on a scale of 1-10 points, where 10 is "extremely satisfied"). $(1,2,3,4,5,6,7,8,9,10)$ \\
Q4 $\begin{array}{l}\text { How easy was it to use the check sheet? } \\
\text { (very easy to use/easy to use/difficult to use/very difficult to use) }\end{array}$ \\
Q5 Please describe your satisfaction with your doctor's explanation and communication with your doctor. \\
(satisfied/almost satisfied/dissatisfied/very dissatisfied) \\
Q6 Did writing a check sheet make you feel uncomfortable? \\
(uncomfortable/a bit uncomfortable/not uncomfortable)
\end{tabular}

sician. All respondents reported that the check sheet was easy to use. Only one respondent felt uncomfortable with completing the check sheet. 
Table 5 チェックシートをお使いの皆さまへ チェックシート及び治療選びについてのご質問

1 治療選択意思決定支援チェックシートは治療選択をする際考えを整理するのに役立ちましたか？ iかなり役立った ii 少し役立った iii あまり役立たなかった ivまったく役立たなかった iv とお答えのかたは理由を教えてください。（）

2 治療選択意思決定支援チェックシートにより医師に質問したり疑問点を話したりしやすいと感じましたか？ iかなり話しやすかった ii 少し話しやすかった iii 少し話にくかった iv 話しにくかった

3 治療に関する医師の説明や医師との話し合いで十分聞きたいことをきき納得の得られる話ができたでしょうか? 10 点を満点とした場合納得の度合いをお教えください.

$10,9,8,7,6,5,4,3,2,1$

4 チェックシートの使いやすさはいかがでしたか? i とても使いやすい ii まあまあ使いやすい iii 使いにくい iv 非常に使いにくい

5 医師の説明や医師とのコミュニケーションについての満足度について教えてください. i 満足 ii ほぼ満足 iii 不満 iv 非常に不満

6 チェックシートを記入することで不快なことがありましたか？ i不快だった ii やや不快だった iii 不快ではなかった

ありがとうございました.

Table 6 Questionnaire on evaluation of the check sheet $(n=3)$

\begin{tabular}{|c|c|c|}
\hline & Questions & $\begin{array}{l}\text { Answer of } \\
\text { participants }\end{array}$ \\
\hline Q1 & $\begin{array}{l}\text { By using the check sheet, have the patient's questions become easy to understand and easy to explain? } \\
\text { (very good/good/not very good/not good) }\end{array}$ & $(0 / 3 / 0 / 0)$ \\
\hline Q2 & $\begin{array}{l}\text { Do you think writing a check sheet has helped to summarize the patient's thoughts? } \\
\text { (think very so/think so/do not think so/do not think at all) }\end{array}$ & $(2 / 1 / 0 / 0)$ \\
\hline Q3 & $\begin{array}{l}\text { Did using the check sheet interfere with the usual medical examination procedure? } \\
\text { (very troublesome/rather troublesome/did not change much) }\end{array}$ & $(0 / 2 / 1)$ \\
\hline Q4 & $\begin{array}{l}\text { Do you think the check sheet will be useful for communication with patients? } \\
\text { (think very so/think so/do not think so) }\end{array}$ & $(0 / 3 / 0)$ \\
\hline
\end{tabular}

Table 7 担当医のみなさまへ がん治療選択支援チェックシート評価についてのお願い

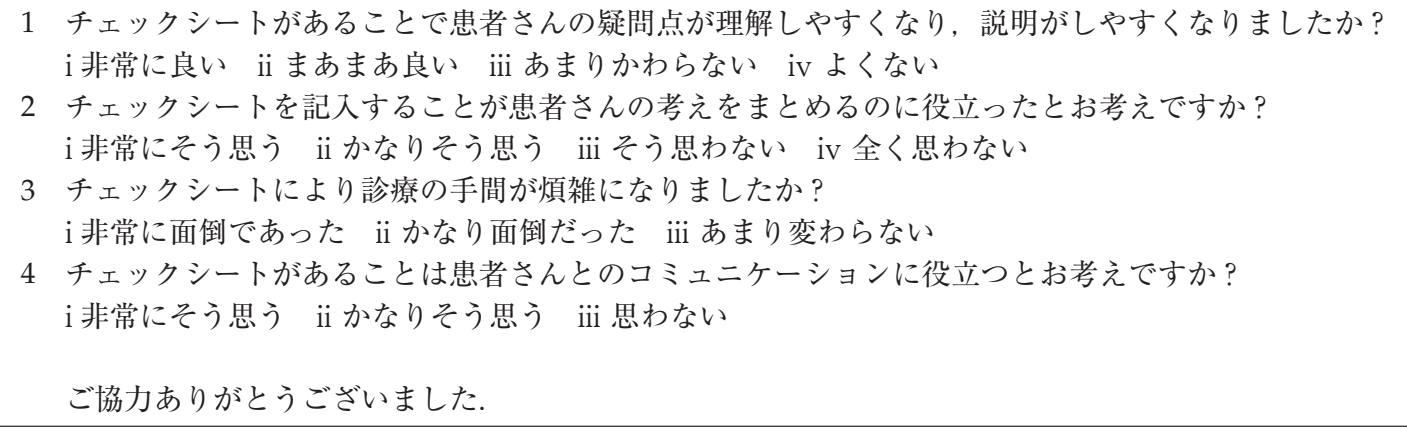

\section{Questionnaire on Evaluation of the Check Sheet}

Three physicians explained the medical condition using the check sheet, and all physicians were listed in the questionnaire. Feedback clearly indicated that the check sheet helped patients organize their ideas and communicate with doctors. However, there was concern that introduction of the check sheet into clinical practice would increase the administrative burden on physicians.

\section{Discussion}

We found that answering the check sheet in advance and receiving an explanation of the medical condition and treatment helped patients to summarize their ideas on treatment selection and made it easier for them to talk with their doctors. The doctors also evaluated whether using the check sheet to explain the treatment options was useful for communicating with the patient. Both pa- 


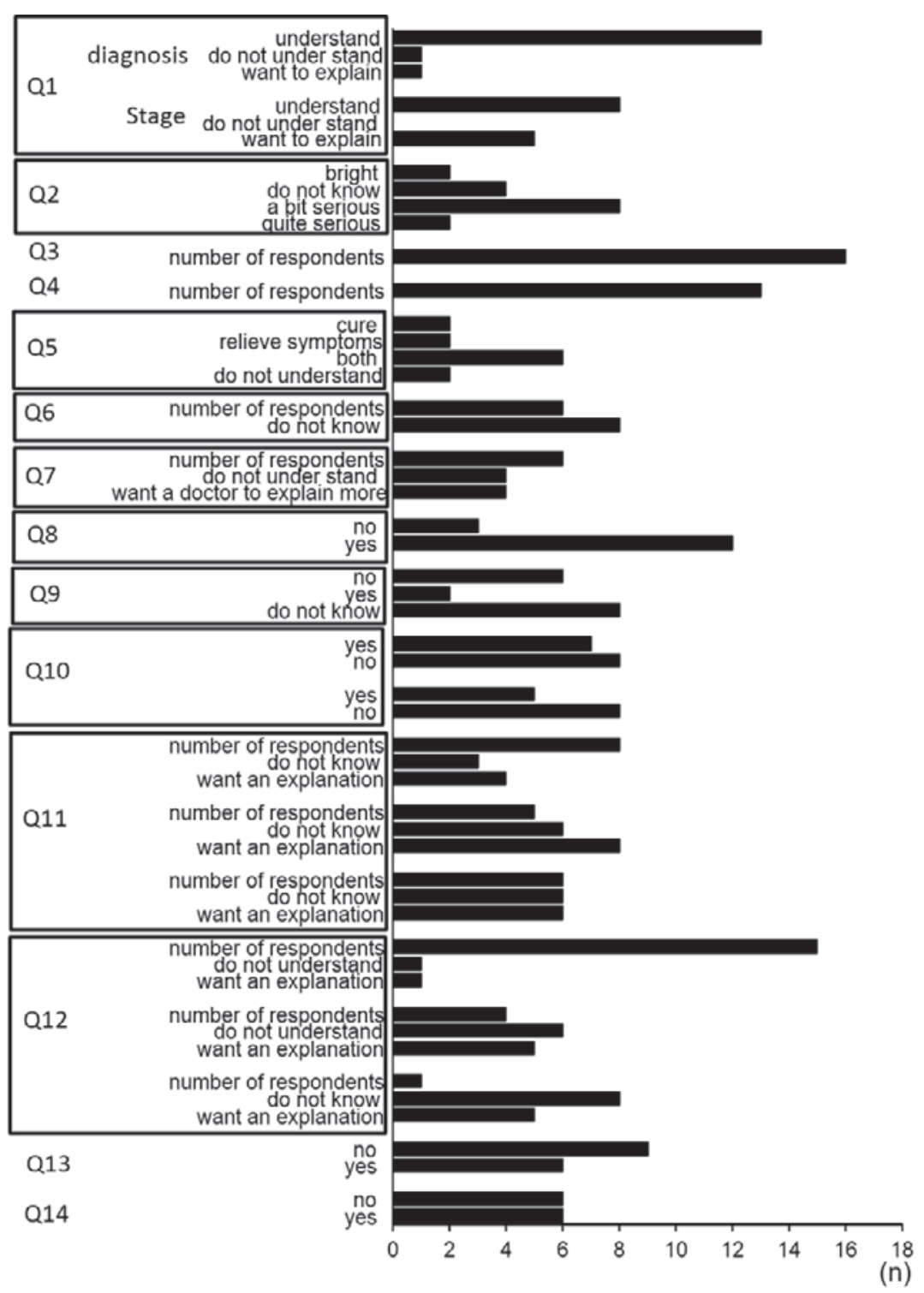

Fig. 1 Results of check sheet on treatment selection.

Q1: Do you know the diagnosis of your illness and stage? Diagnosis and Stage.

Q2: How do you think your prospect of sickness?

Q3: What kind of treatment was explained to you by the doctor?

Q4: What is the most comment treatment for your illness?

Q5: Is the purpose of the treatment to cure the disease or only relieve symptoms?

Q6: Which treatment do you think was good for you?

Q7: Were you given an explanation about the possibility of side effects?

Q8: Are you concerned about the planned treatment?

Q9: Do you want to receive treatment (including folk remedies) other than the treatment presented by your doctor?

Q10: Do you feel anxious about the potential costs of treatment? Would you like know how to get economic support?

Q11: How do you think about your job during the treatment period? Do you think that the treatment will interfere with everyday life? In particular, do you think that treatment will interfere with eating meals?

Q12: How long do you think you will need hospitalization? How long do you think you will need outpatient treatment? Do you think that you will need additional help during treatment?

Q13: Would you like an explanation about palliative care and hospice care?

Q14: In addition to these questions, please write if you have anything else you want to ask doctor. 


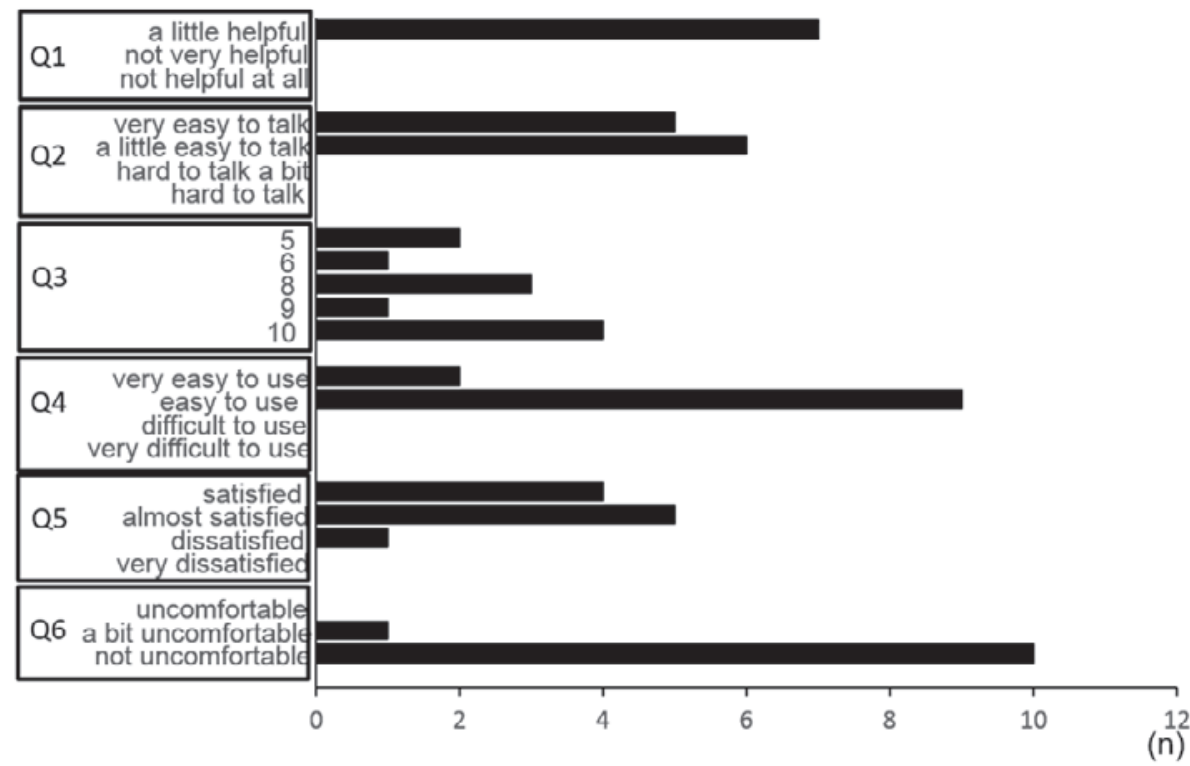

Fig. 2 Results of questionnaire on check sheet and treatment selection. Q1: Did the check sheet help you to organize ideas when selecting treatment?

Q2: Did you feel that the check sheet made it easier to ask doctors or talk about questions? Q3: Did you fully understand the treatment options after listening to the doctor's explanation, and was your talk with the doctor satisfactory? Please express your satisfaction on a scale of 1-10 points, where 10 is extremely satisfied.

Q4: How easy was it to use the check sheet?

Q5: Please describe your satisfaction with your doctor's explanation and communication with your doctor.

Q6: Did writing a check sheet make you feel uncomfortable?

Table 8 Check sheet on treatment selection (Revised version)

Q1 Do you know the diagnosis name and stage (degree of disease progression) of your illness?

\section{Diagnosis}

Stage

Q2 How do you view the prospect (about the future) of your illness?

the outlook is bright, cannot say anything, a little serious, very serious

Q3 How much do you want to know about the potential for future illness? want to know in detail, want to know to some extent, do not want to know

Q4 What kind of treatment was explained by the doctor? ( )

Q5 How was the explanation of the purposes of treatment? (multiple answers allowed) cure, life extension, symptom relief, do not know

Q6 Which treatment did you personally think was the best? ( ), do not know

Q7 Did you get a satisfactory explanation of the possible side effects that may accompany the treatment you will receive? ( ), do not know, please explain

Q8 Are you concerned about the treatment you are about to choose? Please describe the contents if you are concerned. nothing, yes, ( )

Q9 Are you concerned with the costs of your treatment? yes, no Would you like an explanation of how you can economic support? yes, no

Q10 How do you anticipate your job situation will change during treatment? ( ), do not know, please explain

Q11 Do you think that problems will arise in everyday life during treatment? ( ), do not know, please explain

Q12 In particular, do you think there will be a problem with meals during treatment? ( ), do not know, please explain

Q13 How long do you understand the hospital stay will be? ( ), do not know, please explain

Q14 How long do you understand the duration of outpatient treatment will be? ( ), do not know, please explain

Q15 How much assistance do you think you will need during hospitalization or outpatient visit? unnecessary, do not know, please explain

Q16 Would you like an explanation about palliative care and hospice care? yes, no

Q17 Do you have anything else you would like to ask your doctor? Please list if any. yes, no 
Table 9 治療選択に関するチェックシート（改訂版）

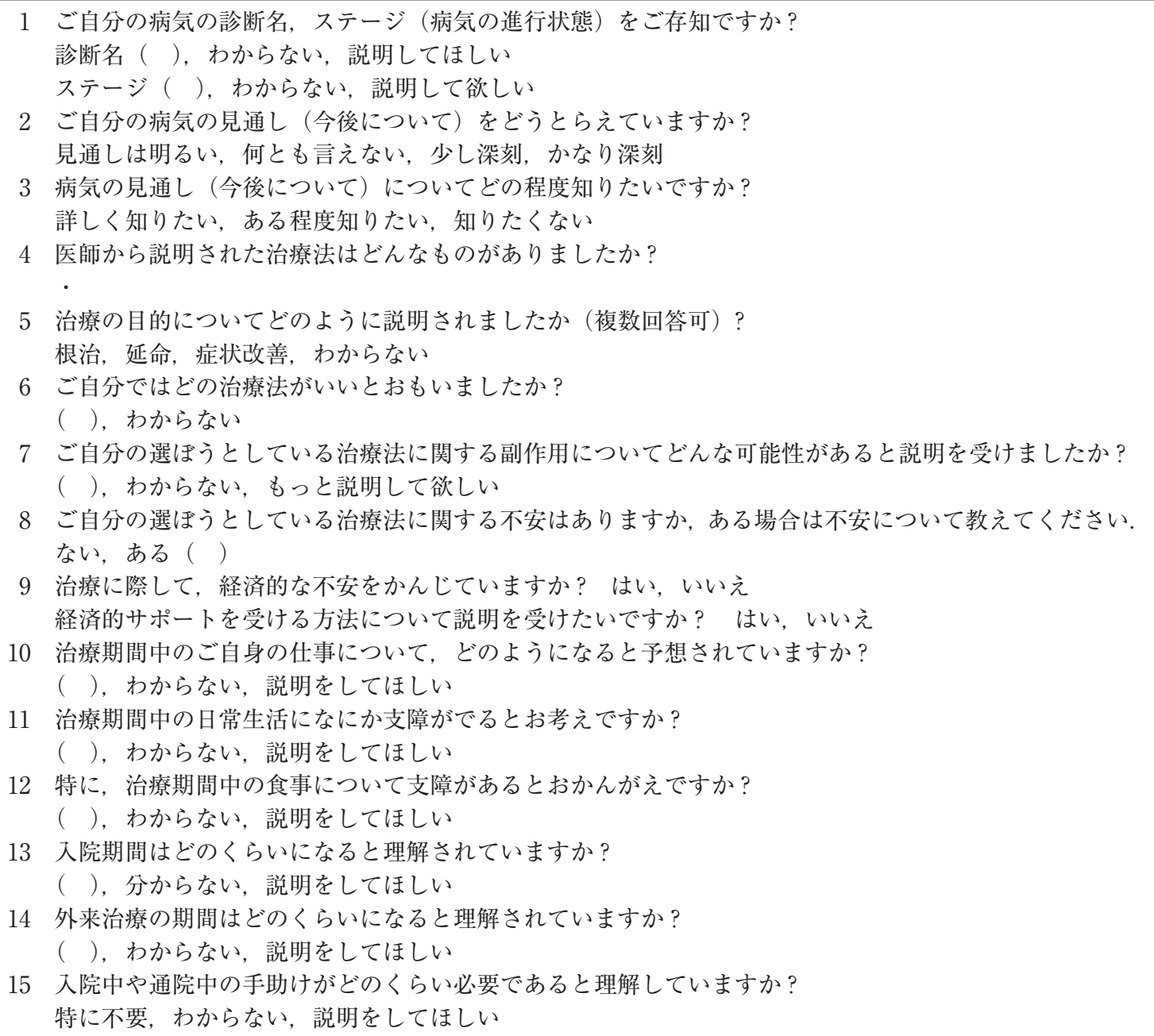

tients and doctors concluded that the check sheet was useful. A previous study of cancer patients reported that formation of rapport between doctor and patient increased satisfaction with the chosen treatment; indeed, achieving a rapport was more effective than increasing the degree to which a patient participated in decisions regarding treatment and providing more information related to the patient's diagnosis or treatment modality ${ }^{1}$.

In psychiatry, it is widely recognized that formation of rapport with patients begins with listening to them; this approach has also been applied to cancer treatment in Western countries ${ }^{26-30}$. In one study aimed at increasing satisfaction with treatment, patients were asked for their preferences related to quality or length of life and who should make the decision before providing medical care ${ }^{31}$. Similarly, Umihara et al. suggested that listening to a patient's needs before treatment also plays an important role in rapport formation ${ }^{1}$. Our findings support these conclusions, since the check sheet enhanced communication between doctors and patients. In addition, Watanabe et al. reported that patients who reluctantly accepted treatment despite being poorly informed felt dissatisfied with the decision-making process ${ }^{6}$. If the check sheet helps patients to ask questions, and improves information sharing between physicians and patients, satisfaction with treatment selection will likely improve.

In the present study, doctors went through several processes, including explanation of the check sheet, agreement, distribution, and collection. Because they had no assistance from other medical professionals, two of the three doctors reported that compiling the check sheet was complicated and time-consuming. Therefore, involvement of other healthcare workers, such as nurses, in compiling the check sheet is recommended.

Many patients did not respond to items in the check sheet. Mindful of their physical condition, we did not press them for their reasons for not responding. However, we speculate that in some cases the patients may not have understood the intent of the question. This issue could be resolved by ensuring that other health pro- 
fessionals are present to answer questions about the content of the check sheet after it is distributed.

A limitation of our study is its small sample size of 20. Thus, we could not completely evaluate the usefulness of this check sheet. Future study is needed to develop a more thorough understanding of the usefulness of this questionnaire for patients with several cancers. In future studies, we will increase the number of patients and provide doctors with additional support from other healthcare professionals. One respondent felt uncomfortable with writing the check sheet. Because the patient could not understand the diagnosis and stage of lung cancer, we believe that the deficiency of acceptance of disability might cause the uncomfortable feeling. A future study will determine the characteristics of patients who do not benefit from the present check sheet as a decision support tool. In addition, we would like to simplify the content of the check sheet to a format like that in Table 8 (Table 9).

Finally, to support cancer patients during decisionmaking, even from early after diagnosis, we propose the "E-PUNKs" decision-making support framework, which comprises six steps: 1, responding emotion (E); 2, grasp of patient understanding and perception $(\mathrm{P})$; 3 , clarification of ultimate goal (including not only cure or palliative care but also individual patient goals) (U); 4, necessity of decision support $(\mathrm{N})$; 5 , evaluation of treatment options based on medical knowledge and information (K); and, 6, summarize and confirm understanding of the patient (S). By using this framework, patient satisfaction with the decision-making process would be improved, and doctors would be further enabled to support decision-making.

\section{Conclusion}

The check sheet used in this study was judged by both patients and physicians to be a useful decision support tool that improved communication and the treatment selection process. To facilitate implementation in clinical practice, however, the administrative burden on doctors must be reduced.

The style of decision-making varies by individual, and some patients do not want the responsibility of making treatment choices. Therefore, before using the decision support tool, it is important to determine the decisionmaking preferences of each patient.

Conflict of Interest: The authors declare no conflicts of interest, financial or otherwise.
This work was supported by National Cancer Center Grantin-Aid for Cancer Research and Development, Grant number 23-A-30, 2013.

\section{References}

1. Umihara J, Nishikitani M, Kubota K. Rapport between cancer patients and their physicians is critical for patient satisfaction with treatment decisions. J Nippon Med Sch. 2016;83:235-47.

2. Coulter A. Paternalism or partnership? Patients have grown up-and there's no going back. BMJ. 1999;319:71920.

3. Deber RB. Physicians in health care management: 7. The patient-physician partnership: changing roles and the desire for information. CMAJ. 1994;151:171-6.

4. Lantos J. Informed consent. The whole truth for patients? Cancer. 1993;72:2811-5.

5. Charles CA, Whelan T, Gafni A, Willan A, Farrell S. Shared treatment decision making: what does it mean to physicians? J Clin Oncol. 2003;21:932-6.

6. Watanabe Y, Takahashi M, Kai I. Japanese cancer patient participation in and satisfaction with treatment-related decision-making: A qualitative study. BMC Public Health. 2008;8:77.

7. Nomura K, Ohno M, Fujinuma Y, Ishikawa H. Patient autonomy preferences among hypertensive outpatients in a primary care setting in Japan. Intern Med. 2007;46:14038.

8. Voltz R, Akabayashi A, Reese C, Ohi G, Sass HM. End-oflife decisions and advance directives in palliative care: a cross-cultural survey of patients and health-care professionals. J Pain Symptom Manage. 1998;16:153-62.

9. Slingsby BT. Decision-making models in Japanese psychiatry: transitions from passive to active patterns. Soc Sci Med. 2004;59:83-91.

10. Levine SR. Consumer-driven health care: a path to achieving shared goals. Physician Exec. 2000;26:10-6.

11. Gattellari M, Butow PN, Tattersall MH. Sharing decisions in cancer care. Soc Sci Med. 2001;52:1865-78.

12. Dowsett SM, Saul JL, Butow PN, et al. Communication styles in the cancer consultation: preferences for a patientcentred approach. Psychooncology. 2000;9:147-56.

13. Martinez LS, Schwartz JS, Freres D, Fraze T, Hornik RC. Patient-clinician information engagement increases treatment decision satisfaction among cancer patients through feeling of being informed. Patient Educ Couns. 2009;77: 384-90.

14. Hoffman RM, Hunt WC, Gilliland FD, Stephenson RA, Potosky AL. Patient satisfaction with treatment decisions for clinically localized prostate carcinoma. Results from the Prostate Cancer Outcomes Study. Cancer. 2003;97: 1653-62.

15. Wright S. Patient satisfaction in the context of cancer care. Irish J Psychol. 1998;19:274-82.

16. Degner LF, Sloan JA. Decision making during serious illness: what role do patients really want to play? J Clin Epidemiol. 1992;45:941-50.

17. Deber RB, Kraetschmer N, Irvine J. What role do patients wish to play in treatment decision making? Arch Intern Med. 1996;156:1414-20.

18. Arora NK, McHorney CA. Patient preferences for medical decision making: who really wants to participate? Med Care. 2000;38:335-41.

19. Keating NL, Guadagnoli E, Landrum MB, Borbas C, 
Weeks JC. Treatment decision making in early-stage breast cancer: should surgeons match patients' desired level of involvement? J Clin Oncol. 2002;20:1473-9.

20. Lantz PM, Janz NK, Fagerlin A, et al. Satisfaction with surgery outcomes and the decision process in a population-based sample of women with breast cancer. Health Serv Res. 2005;40:745-67.

21. Levinson W, Kao A, Kuby A, Thisted RA. Not all patients want to participate in decision making. A national study of public preferences. J Gen Intern Med. 2005;20:531-5.

22. Gattellari M, Voigt KJ, Butow PN, Tattersall MH. When the treatment goal is not cure: are cancer patients equipped to make informed decisions? J Clin Oncol. 2002 Jan 15;20(2):503-13.

23. Fujimori M, Akechi T, Akizuki N, et al. Good communication with patients receiving bad news about cancer in Japan. Psychooncology. 2005;14:1043-51.

24. Fujimori M, Akechi T, Morita T, et al. Preferences of cancer patients regarding the disclosure of bad news. Psychooncology. 2007;16:573-81.

25. Barbaret C, Brosse C, Rhondali W, et al. Financial distress in patients with advanced cancer. PLoS One. 2017;18;12:e 0176470

26. Leinberger RL, Janz NK, Musch DC, Niziol LM, Gillespie BW. Discussing driving concerns with older patients: I. vision care providers' attitudes and behaviors. JAMA Ophthalmol. 2013;131:205-12.

27. Fallat ME, Hertweck P, Ralston SJ. Surgical and ethical challenges in disorders of sexual development. Adv Pedi- atr. 2012;59:283-302.

28. Pennacchini $M$, Pensieri $C$. Is non-directive communication in genetic counseling possible? Clin Ter. 2011;162: e141-4.

29. Fallowfield L, Jenkins V, Farewell V, Solis-Trapala I. Enduring impact of communication skills training: results of a 12-month follow-up. Br J Cancer. 2003;89:1445-9.

30. Fallowfield L, Jenkins V. Effective communication skills are the key to good cancer care. Eur J Cancer. 1999;35: 1592-7.

31. Buzaglo JS, Millard JL, Ridgway CG, et al. An Internet method to assess cancer patient information needs and enhance doctor-patient communication: a pilot study. J Cancer Educ. 2007;22:233-40.

(Received, April 7, 2019)

(Accepted, May 25, 2020)

(J-STAGE Advance Publication, June 30, 2020)

Journal of Nippon Medical School has adopted the Creative Commons Attribution-NonCommercial-NoDerivatives 4.0 International License (https://creativecommons.org/licenses/by-nc-nd/4.0/) for this article. The Medical Association of Nippon Medical School remains the copyright holder of all articles. Anyone may download, reuse, copy, reprint, or distribute articles for non-profit purposes under this license, on condition that the authors of the articles are properly credited. 